\title{
FIRST AID FOR PRISONERS OF WAR
}

\author{
Lieutenant-Colonel T. B. STEPHENS, B.Sc., M.B., M.R.C.P.Ed., \\ D.P.M., D.T.M. \& H., R.A.M.C. \\ Consultant Psychiatrist, B.A.O.R.
}

DURING World War II large numbers of prisoners were starved and treated cruelly, particularly by the Japanese and the Koreans, and many died of disease, wounds or malnutrition. Some survived better than others through the intelligent use of what opportunities and resources were available to them. Their lessons bear reiteration in any case, but since 1950 a new dimension has been added by the Chinese, the North Koreans and the North Vietnamese; assaults and deprivations are now psychological as well as physical. Moreover, prisoners can no longer expect to have various experts, including doctors, confined with them and in a position to advise and lead them. They need to know what to do for themselves and first aid is likely to be their only aid.

The shock and bewilderment of the United Nations troops captured in Korea when they learned how they were to be treated is only too well known. Much that has been said and written about these events has overdramatised them and deaths have been ascribed, for example, to "give-up - it is," supposed to be a syndrome with depressive pattern, prolonged staring into space and lethal neglect of physical condition (Kinkead 1960). On the other hand the effects of dysentery and beri-beri have had less attention than they merit. Psychosomatic sequelae too are sometimes important and disabling with manifold increases in a wide variety of complaints for many years afterwards. These are not new and many who were prisoners of either enemy in World War II are well aware of that fact. But the myth of " brainwashing" has, nevertheless, grown beyond the facts.

There are subsidiary myths too and everybody "knows" that the Turks resisted 100 per cent. The full facts have not been published nor is it really clear to what stresses exactly their small number of prisoners were exposed. Similarly, the favourable opinions on the behaviour of the United States Marines as opposed to the United States Army probably owe at least something to dates and places of capture rather than to the inherent quality of the troops. Also rarely mentioned is the fact that thousands of North Koreans " collaborated" or refused repatriation without any very special treatment as compared with the relatively small number of Westerners who behaved badly. In other words "brainwashing" is something of a bogey which should not cause too much concern, and what matters to the prisoner are the attempts which the enemy will make to reduce him physically and mentally, however poor their results in conversion. That they are continuing their efforts is demonstrated by the sequelae to the capture of the Pueblo. They may not have the success they would like in making prisoners adopt their views but they have repeated propaganda victories, and it would be surprising if they did not persist. In any case, they have a long established pattern now, having started with Nationalist Chinese captives, who probably proved to be encouraging material, and going on to the Japanese and United Nations troops.

At all events, prisoners are likely to find that the relief of tension and relaxation afforded by capture ends quickly as the pressure is put on. They find themselves deprived of rest, sleep, food, water, moral support, information and orientation as well as liberty. 
Disease is not treated and wounds are ignored or used as weapons for blackmail. Clothing may be removed, prisoners are given heavy work to do and physical violence or deliberate torture are not unknown. Threats are commonplace and any deceit or dislocation of the prisoners' expectation is permitted. Propaganda, which may be superficially childish, is constant, while there may be a great show of ruthless efficiency and overwhelming control by the captors to increase even further the prisoners' feelings of hopelessness and helplessness.

A part of the physical debilitation which is easily used is sleep deprivation. After a period of resistance oi about seventy-two hours, rapidly progressive deterioration of performance occurs. Attention and self-criticism fail, confusion, irritability and hallucinations occur, and a persecutory tendency occurs in those who have suitably predisposed personalities. This is associated with the appearance of brief sleep patterns on e.e.g. and it is interesting that performance of short self-paced objective tests may be little affected, while performance on externally-paced tests falls off severely. It is postulated that normal mental activity can still go on between sleep pauses provided the subject can control his own timing of effort.

Naturally, in a military prison camp, grouping of prisoners will be inevitable but attempts will be made to ensure that they remain in crowds rather than in organised groups. A crowd is a considerable number of people gathered by chance, having a focus of attention but transitory, loosely integrated and lacking leadership. Such a group is susceptible to slogans, myths, primary or base motives and to emotional appeals rather than to reason. It tends to respond to the "lowest common denominator" and thus to behave in violent and anti-social ways like lynch mobs. If it appoints a leader at all he is likely to be self-selected by his own intemperance and speed of reaction. Members of a crowd tend to be suggestible and imitative and any demagogue can lead a disorganised group to his advantage and its detriment. Facilitation of behaviour apparently acceptable to the group or to its high prestige members can lead to changes of attitudes and practice in group members. It is not difficult to think of ways of manipulating appearances so that Communist ideas are facilitated and democratic ones are not. At all events, the captors will encourage a chaotic unharmonious relationship between prisoners as opposed to a united one. They will disrupt groups, segregate responsible leaders practised in maintaining morale, appoint poor leaders, ridicule constructive efforts, encourage disputes and disloyalty and so on. They will try to prevent the prisoners' own stable organisation which would permit them to examine their environment rationally.

These days a prisoner of war can more or less expect to be subjected to some degree of isolation, restriction of movement and deprivation of more than one sensory modality. In the short term the more severe restrictions lead to impairment of concentration, time sense and memory with perceptual distortion, reduced ability to distinguish between imagination and reality, frequently causing pseudo-hallucinations, and to impaired learning of high information tasks. All this may be associated with slowing of e.e.g. frequencies which may take days to recover. In the long term, personality factors and social stresses have more influence. For example, the mannerisms of others in close confinement become intolerable, restraint leads to tension and this in turn causes symptoms. The severe prolonged headaches suffered by the crew of U.S.S. Triton during the first submerged circumnavigation have been attributed to this. Related symptoms include insomnia, depression, irritability, muscle soreness, reduced initiative and 
impaired memory. Total deprivation is obviously impracticable in a prison camp but an opaque sack over the head and a loud featureless hissing or buzzing noise serve quite well and all prisoners can be left effectively isolated for hours. This process can produce loss of judgement of time sense, of reality and of the relative importance of material and moral values with auditory and visual hallucinations in a surprisingly short time. The impairment of judgement and insight makes the victim increasingly vulnerable to deceit and, ultimately, to complete conversion.

As mentioned earlier we are not concerned here with the effectiveness of the process but with the assault itself, its effects on the prisoner and, finally, his ability to resist and minimise it. Merely to know that these things may happen gives one an advantage over the prisoners in Korea and, even there, there were some whom with courage and determination, were able to resist. Medical knowledge too can be of value and this may be one of the reasons why the Chinese separated doctors from their comrades and sometimes put them all together in one camp. This move requires the counter of passing the information on before capture and means that this should now become part of normal military first aid training.

The most efficient way to resist is to evade capture, and in weighing the chances of surviving an attempt to do so it might be as well to remember that 44 per cent of American prisoners taken in Korea died. Failing evasion, the prisoner must escape. If he does so early he is probably at his fittest, guarded by frontline troops rather than highly motivated experienced guards and has less ground to cover to safety.

Failing these, the war is not over, but the prisoner must rely on himself and his fellow prisoners. It helps to be a calm imperturbable type, not only because this sort of man is the least susceptible but because his captors know it and he is the least likely to be subjected to a sustained enemy assault. Not everybody is equipped in this way but the pretence may suffice. Similarly, the knowledge of the risks of involvement may prevent the prisoner becoming literally and figuratively hypertensive so that he neither exhausts himself by his responses to stress nor makes slips of the tongue in the heat of the moment. The Geneva Convention authorises the captor to ask for number, rank, name and date of birth for identification purposes. Service training is that a prisoner should give these facts and no more. He is advised to be polite to his captors and to avoid shouts and insults which would make it easier for them to work themselves into an ill-temper where violence or other punishments would come naturally. In spite of this, violence is unlikely to be escaped entirely and many feel that this would constitute the most dangerous threat to their integrity. Indeed this would be one of the reasons for its use, particularly early on when information about personality can be as valuable as factual military information.

It may help to remember that any interrogator would be a complete fool if he did not realise that a prisoner who gives information once in response to a beating will do so again when more is required. It is a fact that prisoners who co-operate are often treated worse than resisters in the long run. Refusal to involve oneself should be complete and should extend even to not listening to questions. If one does not intend to answer a question, listening to it can do nothing more than give the questioner at least a slight opportunity of touching some emotional response and beginning the erosion of resolve.

The preservation of physical fitness against odds is obviously important not only for the resister but for the potential escaper, which every prisoner should continue to be. 
The matter of exercise may be a problem. Some of the heroes who have resisted have tended to emphasise the value of marching up and down and keeping themselves active. In certain situations this is undoubtedly helpful but perhaps not so much as a means of keeping fit; it is known that bodily movement, even small movements of digits, can delay the effects of isolation and deprivation significantly. On the other hand, the prisoner of war may have an entirely different problem in that he may be marched long distances, carrying heavy weights, inadequately clothed and fed and given insufficient opportunities for rest and sleep. For him a determination to snatch every opportunity for sleep is most important. Either way, the prisoner is likely to experience fatigue, possibly just as much when under-employed as when over-exercised. It may be a fact, though some find it difficult to accept, that fatigue is " only" a psychological mechanism designed to prevent organic damage and going into action in frustrating or physically stressful situations long before there is any appreciable danger of harm.

Some prisoners may be wounded and demand help, not only for moral reasons, but because shock and debility produced by wounds increases susceptibility to brain washing and therefore increase the chances of their being a weak spot in the wall of resistance.

Nutrition too is important and it is surprising how much can be made of unpromising materials. Men have survived for years alone in jungles and some prisoners managed much better than others in Korea. One of the best examples of what can be done happened in Singapore from 1942 on. Among the civilian prisoners of the Japanese were a number of members of the staff of the General Hospital who examined nutrition and sought for dietary supplements to combat malnutrition. They achieved dramatic benefits by growing their own poor quality vegetable foods and by insisting on obtaining and eating the sweepings of the rice factory floor for the rice polishings and weevils to be found therein. Naturally, conditions vary and opportunities for improvisation are not predictable, but what is important is that essential vitamins and nutrients can often be obtained from animal and vegetable sources which are normally not regarded as edible. Table I shows in abbreviated form the sort of thing which may be done. It assumes the issue of a diet which is as poor as any a prisoner might expect to receive and of a type such as he might get in South East Asia today. It involves a large volume of rice and offers him an average of 1900 Calories and $37 \mathrm{~g}$ of protein daily. For an adult Caucasian male doing physical work this would result in rapid loss of weight with polyuria which would be followed in due course by beri-beri, keratomalacia, osteoporosis, anaemia and pellagra. The effects of climate are ignored and, indeed, are probably of little real importance to calorie requirements in all except conditions of extreme cold. Vitamin D requirement is considered though it is unimportant in adult males especially if they are in a sunny climate with a certain amount of animal fats to provide a source of 7 dehydrocholesterol. It is obvious that the total requirements which have been assumed are the minimum and it should also be noted that they are balanced so that for example, an increased availability of protein would demand a greater intake of niacin. The protein intake itself is also the currently fashionable minimum requirement and ignores the effects of wounds or other protein-losing conditions. The essential points of the table are that it shows the sorts of dietary supplements which may be available and be ignored, that even a sole supplement of $600 \mathrm{~g}$ a day of "spinach" obviates all important deficiencies except calories and that animal foods not normally consumed in our culture are highly valuable in fact. "Spinach" is any green leaf which is neither poisonous 
Table I

Daily dietary supplements to $520 \mathrm{~g}$ rice daily plus $20 \mathrm{~g}$ dried fish twice weekly

\begin{tabular}{|c|c|c|c|}
\hline & $\begin{array}{l}\text { Assumed total } \\
\text { requirements }\end{array}$ & $\begin{array}{l}\text { Supplements } \\
\text { necessary }\end{array}$ & Possible sources \\
\hline Calories & 2800 & 900 & $\begin{array}{l}\text { Acorns }(450 \mathrm{~g}) \text {, insects }(500 \mathrm{~g}) \text {, } \\
\text { durian }(400 \mathrm{~g}), " \text { spinach " }(2000 \mathrm{~g})\end{array}$ \\
\hline Protein & $50 \mathrm{~g}$ & $13 \mathrm{~g}$ & $\begin{array}{l}\text { Dogs, rats, snakes, insects, mushrooms, } \\
\text { "spinach" ( } 250 \mathrm{~g})\end{array}$ \\
\hline Calcium & $800 \mathrm{mg}$ & $700 \mathrm{mg}$ & Insects, " spinach" (350 g) \\
\hline Iron & $12 \mathrm{mg}$ & $9 \mathrm{mg}$ & Insects, “ spinach ” (300 g) \\
\hline Vitamin $\mathrm{A}$ & 5000 I.U. & 5000 I.U. & $\begin{array}{l}\text { Red chilli, mushrooms, fish, } \\
\text { " spinach" }(50 \mathrm{~g})\end{array}$ \\
\hline Vitamin D & 300 I.U. & $50 \mathrm{I} . \mathrm{U}$. & $\begin{array}{l}\text { Mushrooms, animal fat, " spinach" } \\
(700 \mathrm{~g})\end{array}$ \\
\hline Vitamin B & $\begin{array}{l}\text { Thiamine } 0.8 \mathrm{mg} \\
\text { Riboflavine } 1.7 \mathrm{mg}\end{array}$ & $\begin{array}{l}0.4 \mathrm{mg} \\
1 \mathrm{mg}\end{array}$ & $\begin{array}{l}\text { Cellular foods } \\
\text { "Spinach" }(600 \mathrm{~g})\end{array}$ \\
\hline Niacin & $7 \mathrm{mg}$ & $1 \mathrm{mg}$ & Fish, "spinach" (10 g) \\
\hline $\begin{array}{l}\text { Ascorbic } \\
\text { acid }\end{array}$ & $20 \mathrm{mg}$ & $20 \mathrm{mg}$ & Fruit, " spinach" (30 g) \\
\hline
\end{tabular}

nor too acrid to eat and includes weeds and leaves of trees. Its nutritive value varies, but on average it is probably better than the domestic variety and its taste and appearance are probably not much worse. The animals listed are apt to be rejected with nausea but if it walks, crawls, swims or flies it can be eaten provided poison glands are removed and provided it is cooked. Prisoners may have to be persuaded of this, particularly so if there are religious taboos.

Similarly, prisoners need to be educated about hygiene which can so easily be neglected if apathy sets in and leads to a vicious circle of disease, debility and inactivity. The provision of proper latrines and their flyproofing should not be beyond the ingenuity of prisoners if they have any freedom at all and the control of hookworm infestation by clearing vegetation away from buildings and human movement so as to discourage defaecation in its shelter is a classic. Liquids and foods must all be boiled not only to control enteric diseases but to prevent worm infestations. Water contaminated with the cercariae of schistosomiasis must not be touched or consumed. Primitive mosquito control by attention to stagnant water may be possible to reduce not only malaria but filariasis, and the daily removal of lice may not be adequate to prevent typhus but it can reduce anaemia, a disease which may well be more important in practice.

In the sphere of treatment too it may be possible to do more than one might think at first sight. If proper treatments are available, very well, but, in their absence symptomatic management may be effective. For example, the curse of the Asiatic prison camp is diarrhoea, and charcoal, bark and tea are all of value for this, as is the blackboard chalk which is likely to be available for political indoctrination classes. Tapeworms may be reduced at least by an ounce of paraffin or petrol taken fasting and away from 
naked flame, and in the treatment of wounds both maggots for debridement and urine for sterile washing are likely to be readily available.

Clearly these measures for improvement in nutrition, health and hygiene are appropriate in the long term rather than at once, but the psychological pressures are present throughout and are perhaps most important in the early days. It is then that prisoners will need to form their attitudes of resistance and unity. The captors will try to impair loyalty and trust. Resistance will require the encouragement of those qualities, not so much to the heroic resisters and escapers who easily command one's admiration, but to the weaker ones who are collaborating or who are deceitfully made to appear to be so by the captors. It may be hard to believe that the well-fed and clean and comfortable prisoner is not being rewarded for services rendered to the enemy but it does no harm to hold to that belief and it may well be correct.

It may be equally difficult to resist the reverse position i.e. the small reward given for much effort and prolonged suffering. If one has striven mightily and achieved little a dissonance arises which cannot be resolved by cancelling the past effort. The tendency is, therefore, to re-evaluate the reward as to show that all that effort was worthwhile after all. If the reward is materially small it becomes necessary to find an idealised motive and here lies the danger, because it may seem that the only thing that can make all those months of abject misery worthwhile is the " reward" of conversion to Communism. It helps to remember that this is not true and it should help even more to take no rewards whatsoever from the captors. One should take what one can get, but not if there are strings attached.

A strong discipline founded on the military organisation before capture provides support, raises morale and maintains confidence that all is not lost and resistance continues to be worthwhile. Similarly, firm religious beliefs are protective, though it has been observed that it is not always the religious fervour which seems strongest which is best for the purpose. Sometimes, if fervid religious beliefs can be undermined the prisoner is left without defence whereas his less demonstratively religious fellows manage to carry on.

Being too clever is often a mistake and the joke at the expense of a stupid indoctrinator may misfire badly merely by being taken seriously and unimaginatively. Malingering and simulation of mental illness are asking for trouble as detection leads to curiosity about what the initiative is for.

One must admit that much that is said about resistance is a doctrine of perfection and that many or most would find these precepts demanded too much of them. However, if a prisoner can stick it he can win and while he suffers he can console himself with the thought that he is better off than those who have given the captors reason to suppose that pressure will be effective. There appears to be growing pressure to condone or even advise collaboration in prisoners of war. In my view this does not help the prisoner at all in the long run and would have disastrous effects on group and even national morale and I quote, with approval, from Executive Order 10631, Code of Conduct for Members of the Armed Forces of the United States (1955).

"If I am captured I will continue to resist by all means available. I will make every effort to escape and to aid others to escape. I will accept neither parole nor special favours from the enemy. When 
questioned, should I become a prisoner of war, I am bound to give only name, rank, service number and date of birth. I will evade answering further questions to the utmost of my ability. I will make no oral or written statements disloyal to my country and its allies or harmful to their cause ... . I will trust in God and in the United States of America."

It has been argued that it is all very well to sit in comfort and safety and tell the prisoner how he ought to behave. This is not the point. To face in imagination a situation which would be intolerable and to decide that one could not resist it and therefore to counsel that better men should reduce their performance to one's own poor level is a doctrine of despair. It does no more than reduce one's self-doubts by making out that the whole thing is too much for any man and it provides no support for those who are unfortunate enough to find themselves in a real prison camp. It might be worth bearing in mind too that others will not be captured and their very lives may depend on the prisoners' behaviour, as may the morale and image of the whole nation.

It seems inescapable that the prisoner must set out to resist absolutely from the beginning. He must escape if he can but failing that he must continue to fight his war with intelligence, courage, determination and knowledge. He may fail and he may become a casualty but so may his comrades who continue to fight outside captivity.

\section{REFERENCE}

KinKEAD, E. (1960) Why they Collaborated. Longmans, London.

\section{University of Edinburgh}

The Degree of Doctor of Medicine (M.D.) was conferred on Brigadier J. MackayDick, O.B.E., F.R.C.P. on 10th December 1969, by the Faculty of Medicine of the University of Edinburgh.

\section{Order of St. John of Jerusalem}

Those recently appointed to, or promoted in, the Most Venerable Order of the Hospital of St. John of Jerusalem include the following:-As Serving Brothers. Majors M. F. Kirkman. N. E. Shaw. 